\title{
THE PALEOGENE TECTONOSTRATIGRAPHY OF NORTHERN PART MASALIMA TRENCH BASIN
}

\author{
Luhut Pardamean Siringoringo $^{1} *$, Dardji Noeradi ${ }^{2}$ \\ ${ }^{1}$ Sumatera Institute of Technology, South Lampung, Indonesia. \\ ${ }^{2}$ Bandung Institute of Technology, Bandung, Indonesia
}

* Corresponding Author: Luhut.pardamean@itera.ac.id

Tel.: +62-813-1120-8367

Received: Oct 1, 2016. Revised : 15 Nov 2016, Accepted: Nov 20, 2016, Published: 1 Dec 2016 DOI: doi.org/10.24273/jgeet.2016.11.2

\section{Abstract}

Northern part of Masalima Trench Basin is located in the southern part of the Strait of Makassar, which includes Masalima Trough and Massalima High. The area of research is an extension of the South Makassar Basin which extends from South Makassar Basin to the Northeast part of Java Sea. Subsurface data are used such as 2D seismic sections (21 lines) and data drilling wells ( 2 wells) to understand the tectonic structure in the basin formation and understand the stratigraphic order of basin.

Based on well data can be known that Northern part Masalima Trench Basin is aborted rift because marked by post rift phase. Northern part Masalima Trench Basin was formed by normal faults which have trend northeast-southwest with pre rift, early syn rift, late syn rift, and post rift sediment geometry. Early syn rift sediment was Middle Eocene, late syn rift sediment was Middle Eocene till Early Oligocene and post rift sediment was Early Oligocene till Early Miocene. The Depositional environment of early syn rift phase such as beach, shallow marine, and land. The Depositional environment of late syn rift phase such as beach till deep marine, and the depositional environment of post rift is deep marine.

Keywords: Masalima, Tectonostratigraphy, Basin.

\section{Introduction}

\subsection{Background of Research}

Research area is located in northern part Masalima Trench Basin which includes Masalima High, Sibaru High, and Masalima Trough. The area of research is an extension of the South Makassar Basin which extending from South Makassar Basin to the Northeast part of Java Sea (Kupecz dkk, 2013). As extension of south makassar Basin, the tectonic process which happen in research area was estimated very close relation with the forming process of South Makassar Basin. Because of this, the writer will analyze the forming process of northern part Masalima Trench Basin and its filling. Beside that, the research area is the one of minimum research areas, it can be known from publications of research area which still few. Hopefully, this research will add existing publications especially about the forming process of northern part Masalima Trench Basin.

In Indonesia map, the research area is located on the south west of offshore south Sulawesi province or southeast Kalimantan island, and located in the north of Lombok Island (Fig. 1).

The topics of research including the geometry of research area especially from Middle Eocene to Early Miocene which is estimated different from South Makassar Basin's geometry. And then, sedimentary pattern on northern part Masalima Trench Basin from syn rift to post rift.

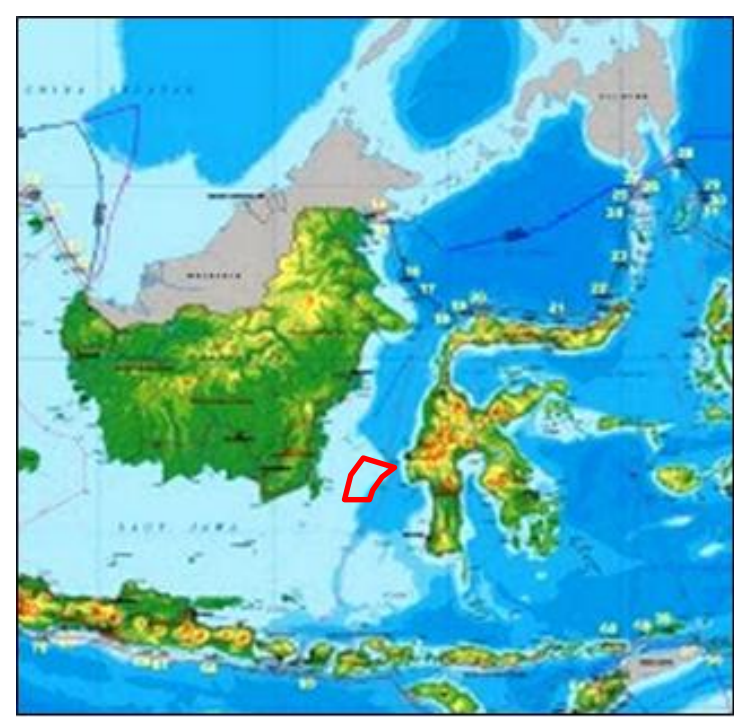

Fig. 1. The location of research area (red line)

The purposes of this research area are to know the forming mechanism and filling of northern part Masalima Trench Basin in Paleogene age.

The hypothesis of research are Masalima Trench Basin was estimated aborted rift and North-East trend faults are dominantly control sedimentary pattern at Masalima Trench Basin. The basic 
assumption is sedimentary thickening showing basin configuration on sedimentation.

\subsection{Methods of Research}

The main data that be used in this research are 21 2D lines seismic and two wells data (fig. 2). Two well data are Alfa well and Beta well. Alfa well data including bore hole descriptions, biostratigraphy data for determine age and bathymetry zone, and wireline logging. Wireline logging data are gamma ray log, density log, resistivity log, and sonic log.

Meanwhile, Beta well data are bore hole descriptions, biostratigraphy data for determine age and bathymetry zone, and wireline logging. Wireline logging data are gamma ray log, density log, resistivity log, and induction log.

The beginning of research was literature study about research area. Then, continued collecting 2D seismics and wells data. Well data consist of bore hole descriptions, biostratigraphy data to determine age and bathymetry zone, and wireline logging. Seismic data be used for pulling tectonostratigraphy units boundaries and faults. After that, continued did well seismic tie. After tied, continued to determine interval composition of every tectonostratigraphy unit and make isochron map to know thickening of sedimentary pattern. At the last step of research were to know forming mechanism and basin sedimentary filling (fig. 3).

\section{Regional Geology}

\subsection{The Regional Tectonic of South Makassar Basin}

Research area is located in northern part Masalima Trench Basin which includes Masalima High, Sibaru High, and Masalima Trough. The area of research is an extension of the South Makassar Basin which extending from South Makassar Basin to the Northeast part of Java Sea (Kupecz et al, 2013).

South Makassar Basin was formed in the southeast of Sundaland that was influenced by three large plates: Eurasia, India-Australia, and Pacific. It is bordered by Adang fault zone in the north and West Sulawesi fold belt in the east part. In the south bordered by Masalima High, and in the west bordered by Paternoster Platform (Hidayat et al, 2012).

Masalima Basin in special term, is a part which tighten in the tip south west of South Makassar Basin. It is bordered by opening to South Makassar Main Basin in the north, Masalima High in the east, north platform in the south, and Sibaru High in west (Hidayat et al, 2012) (fig. 4).

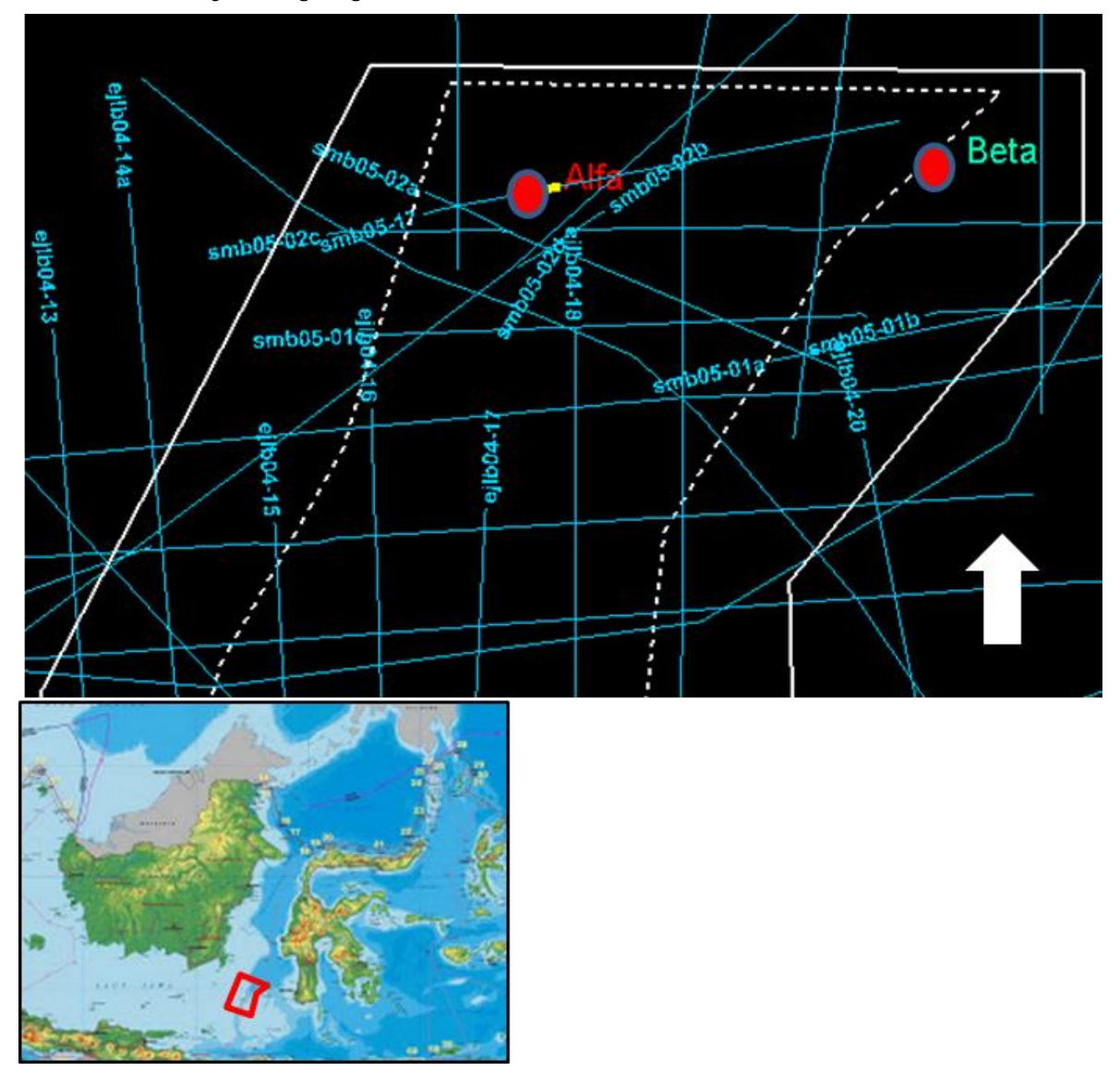

Fig. 2. The data including $212 \mathrm{D}$ lines seismic and two wells 


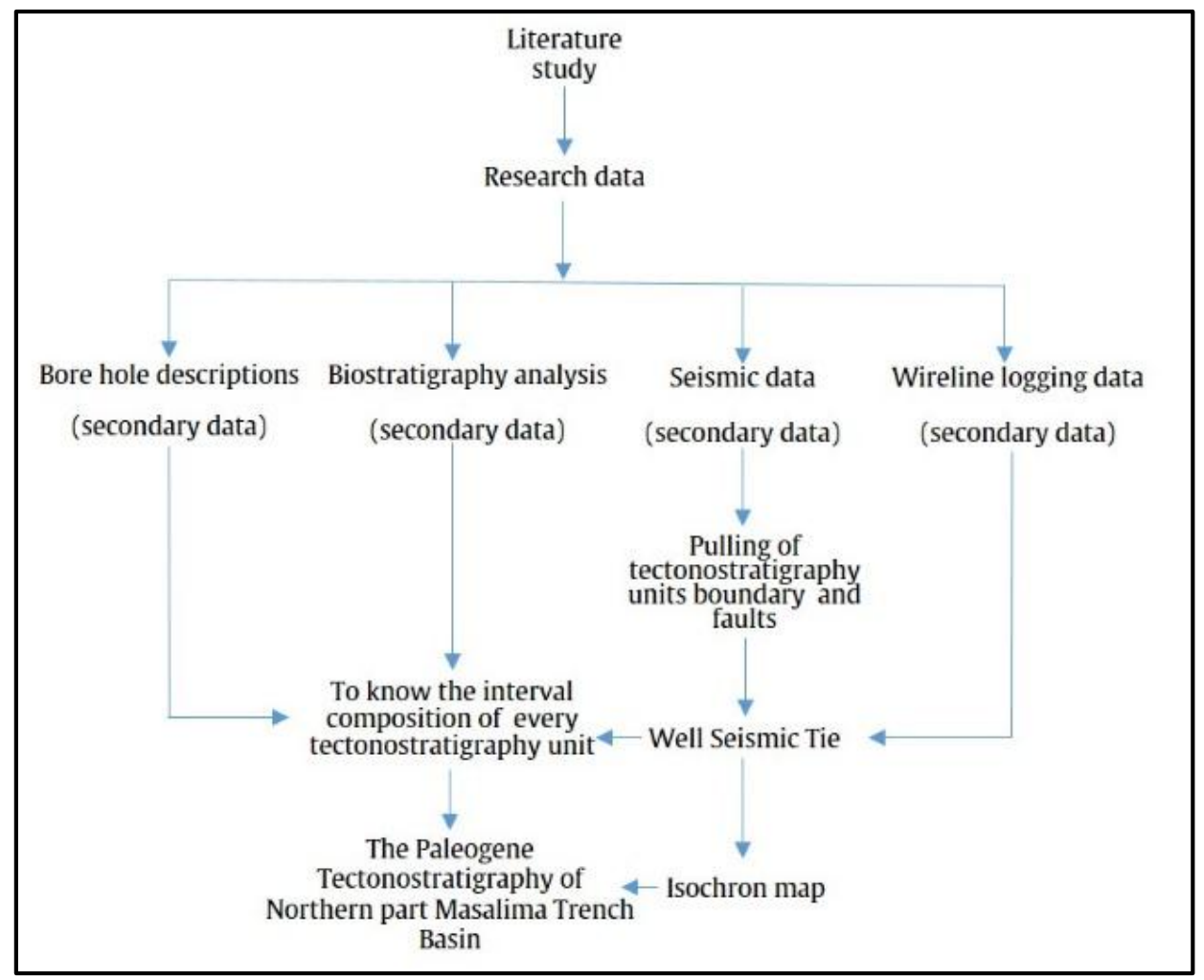

Fig. 3. The Flow chart of research

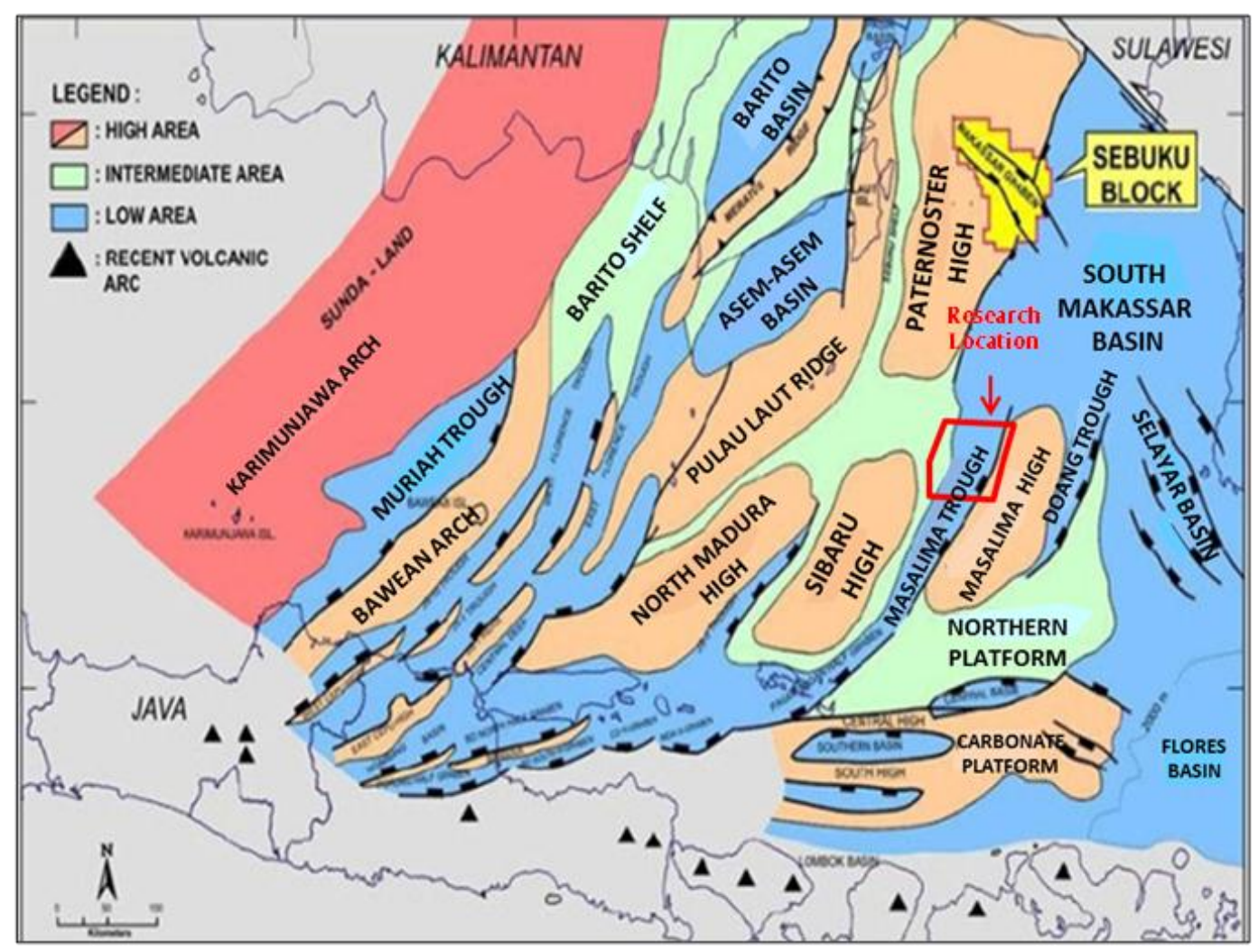

Fig. 4. The research location area in South East Sundaland structure skeleton map (Hidayat et al, 2012) 
In the research area, the oldest sediments were estimated from Paleocene consist of coal, sandstone, and claystone that are interpreted from land deposit. The rifting process maybe begun from Middle Eocene and ended in last Eocene. Eocene sediments were deposited in graben and half graben at sea environment and land (Pireno et al, 2009).

Based on regional data, the tectonic history of south Makassar Basin can be divided into two phases of tectonic, they are Extensional and Compresional Phase.

1. Extensional Phase.

This phase happen at Middle Eocene till early Miocene and divided in two period, they are:

- $\quad$ Rifting (Middle Eocene-Last Eocene)

This period was presented by graben structure, half graben, and horst with NW-SE and N-S trends (Kupecs et al, 2013). This structures were interpreted as back arc rifting result that caused by subduction in the east part of Sulawesi

Post Rifting and Descent (Oligocene-Early Miocene)

In this period was presented by decreasing of fault activities frequency in rifting period (main fault boundary). In this period, South Makssar Basin experienced descent activity, manifested by maximum transgression, thick sediment, and post rifting sediment spreading (Kupecz et al, 2013).

2. Compressional Phase (Middle Miocene-Last Miocene).

In Middle Miocene till Last Miocene, Button and Banggai-Sula microcontinents collision with East Sulawesi subduction complex. This event produced thrust fault, folding, inversion structure. The evidence of this event can be observed in the east part of South Makassar Basin and Sulawesi land (Sengkang to Kolosi area) (Hidayat et al, 2012)

\subsection{Regional Stratigraphy of South Makassar Basin}

Based on well data, the lithology type in the South Makassar Basin leaning having same type with the regional stratigraphy of Sebuku Basin. Sebuku Basin is located in Kalimantan off shore. So, Sebuku Basin Stratigraphy will be used as reference to name formations in South Makassar Basin area (Hidayat et al, 2012).

The formations that composed South Makassar Basin as follow (Hidayat et al, 2012) (fig.5) :

1. Under Part Tanjung Formation

This formation consist of transition deposits lithology like sandstone, claystone, and coal till shallow marine deposits like carbonates rocks and soft detrital. This formation was deposited on PreMiddle Eocene.

2. Upper Part Tanjung Formation

Maximum transgression on late rifting phase, was caused by descent stoping, that was responsible changed environment to marine. This formation was deposited on Late Eocene, in this phase, the supply of clastic material had been decreased.

This formation was dominated by carbonates platform and bathymetry indicated Neritic Zone with interbeds carbonates clay and limestone that reflecting platform area.

3. Berai Formation.

This formation was deposited when the rifting process had stopped on Oligocene. Berai Formation deposition showed lateral changing from platform environment and carbonates platform to slope and basin plain. From biostratigraphy analysis, carbonates platform was developed in Neritic Zone. 4. Under Part Warukin Formation.

Under part Warukin Formation deposition on early till middle Miocene as same as Berai Formation restively, show ed facies changing little by little from platform facies to slope and basin plain. Under Part Warukin Formation consist of clay-limestone intersbeds on Neritic and Sub Neritic.

5. Upper Part Warukin Formation.

This formation indicated facies changing laterally from platform to slope and basin plain. This formation developed in Neritic and Sub Neritic

6. Dahor Formation.

This formation consist of lithology that had relation with compressional event. Consist of shallow marine transgression sediments like limestone, claystone, and shale. This formation was deposited on late Miocene till Pliocene.

\section{Result}

\subsection{Lithostratigraphy Determination}

To know lithostratigraphy in research area, will refer to Alfa well data because it is the one well which have passed seismic line and stratigraphyly, be estimated is more complete than others because of located inside of basin.

This Alfa well data will be used as referring in determination interval composition every the unit of tectonostratigraphy.

From Fig. 6, can be seen the cutting descriptions result of Alfa well. From this result, the writer compared with the stratigraphy of South Makassar Basin. So, can be concluded that :

From 6.765'to 6.946 is Basement Rocks

From 6.720' to 6.765' is Under Tanjung Formation

From 6.363' to 6.765' is Under Tanjung Formation

- From 6.040' to 6.363' is Under Tanjung

Formation

- From 5.320' to 6.040' is Upper Tanjung Formation

After depth 5.320' to 6.040' nothing information about range of depth, but from lithology was dominated by limestone. This identic with Berai Formation. 

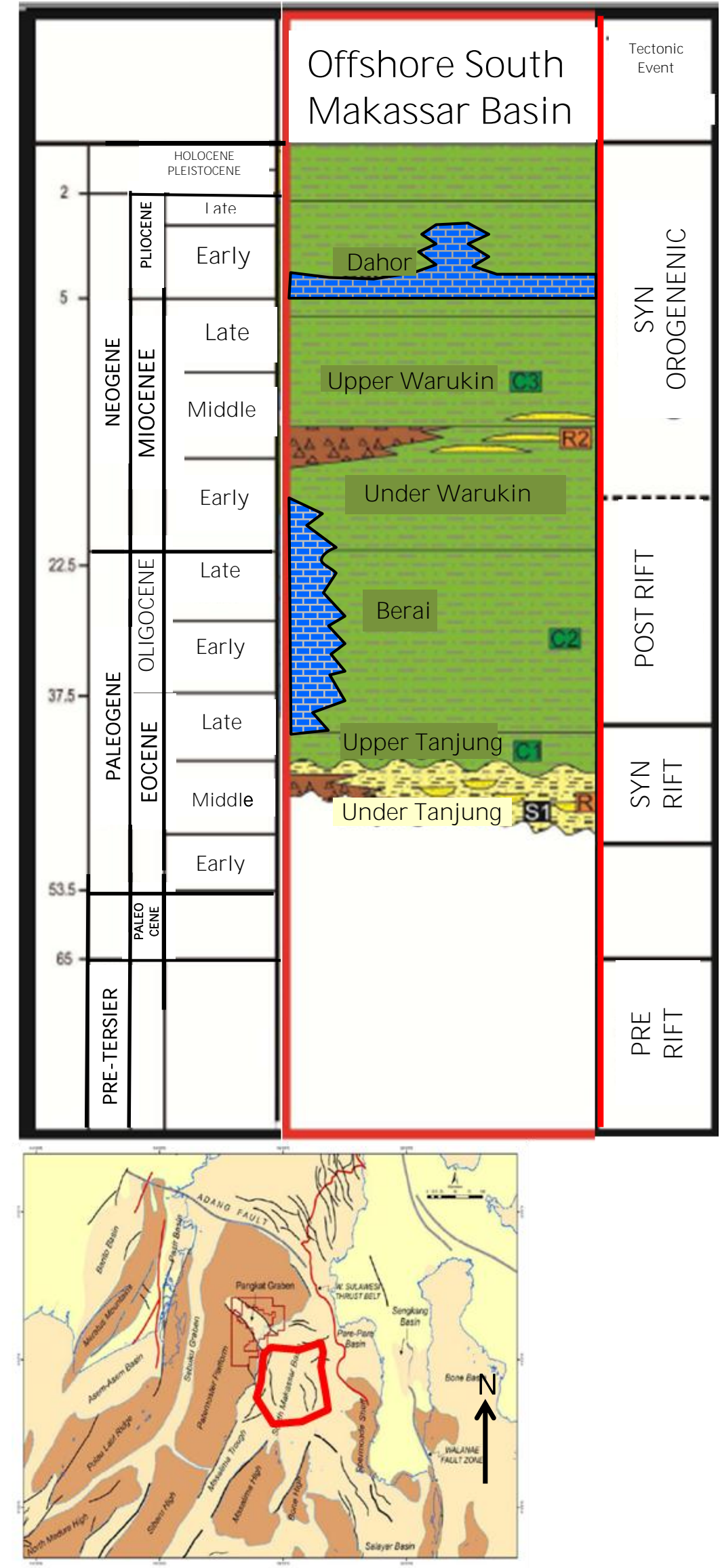

Fig. 5. South Makassar Basin Stratigraphy (Hidayat et all, 2012). 


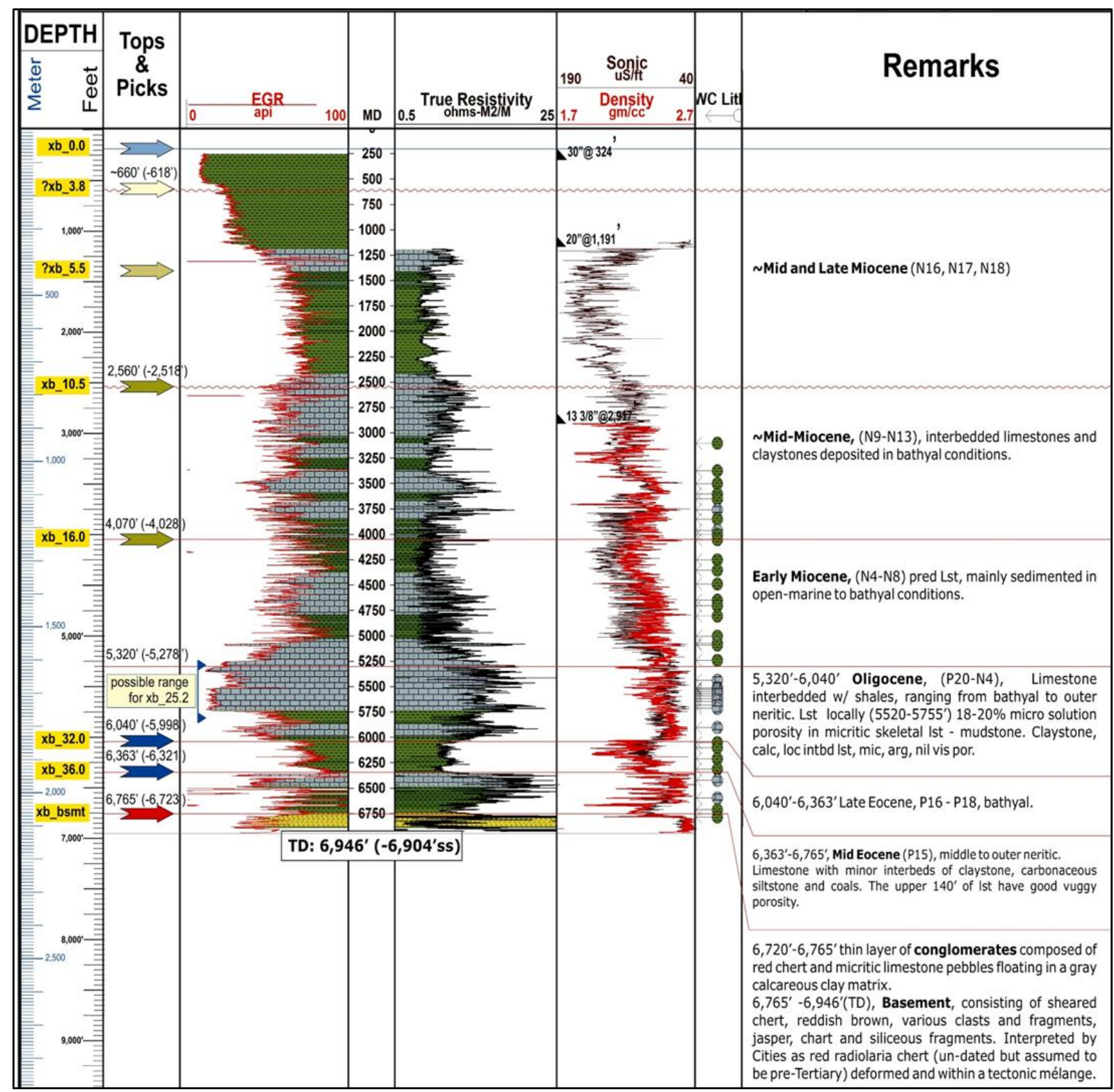

Fia. 6. Alfa well data that shows stratiaranhv comnosition.

\subsection{Tectonostratigraphy Determination \\ Boundary}

To determine tectonostratigraphy boundary, can be used seismic data that featuring every tectonostratigraphy units (pre rift, syn rift, and post rift). The characters of seismic reflector of every unit as follow:

1. Pre rift reflector character.

Strong-medium amplitude, continuous relatively, parallel-sub parallel internal configuration.

2. Syn rift reflector character.

Triangular geometry, thickening to bounding fault, thinning to flexural margin.

3. Post rift reflector character.

Steering horn geometry, thinning to margin and thickening in central basin, thickness changing not be influenced by fault(s).
From observation to SM05-17 section that passed Alfa Well, the interpretation result of tectonostratigrafi boundary can be seen in fig. 7 . From this analysis also concluded that northern part Masalima Trench basin is aborted rift because of marked by presence of post rift interval.

\subsection{Well Seismic Tie}

The next step is well seismic tie to $2 \mathrm{D}$ seismic line (SM 05-17). At this process, correlation coefficient haveto near 1. After did the process, can be known that the best value for correlation coefficient is 0,791 .

After did well seismic tie, next step was to know lithology type of every interval. In research area just only two wells exploration: Alfa and Beta Well. Alfa Well that was passed by seismic section SM05-17, penetrated pre rift sediment was estimated pretertiary but Beta well wasn't passed by seismic line. 


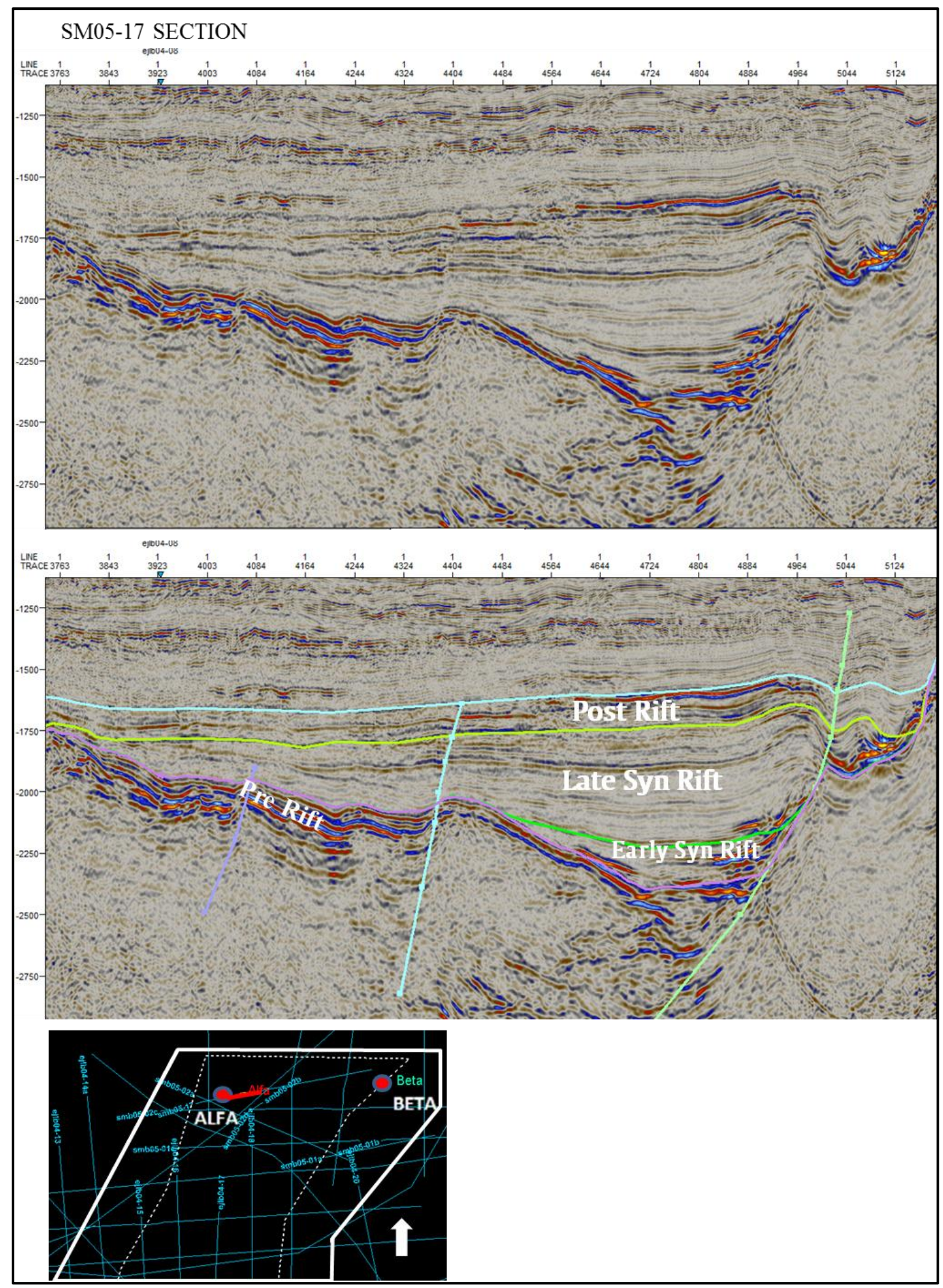

Fig. 7. SM05-17 section: the top is without interpretation, The Bottom is with tectonostratigraphy boundaries interpretations based on reflector patterns 
Fig. 8. Shows Alfa well position and the projections of top tectonostratigraphy intervals. As noted, that alfa well position that be seen at fig. 9 . Located on flexural margin.

From the seismic tie can be known that:

- 6.765'- lower : shared chert and jasper were interpreted as marine sediment which have experienced tectonic process.

- 6.720'-6.765' : conglomerates with red chert fragments and pebble limestone floating in grey calcareous clay matrix. This interval interpreted as marine sediment on litoral condition at beach morphology with high slope. This interval is early syn rift.

- 5.750'-6.720' : limestone interbeds claystone, calcareous siltstone, and coal that changed to be limestone interbeds shale. This interval can be interpreted as beach sediment till marine sediment (neritic environment) (fig. 10). This interval correlates with late syn rift sediment.

- 4.300'-5.750' : limestone interbeds shale (fig.10). this interval was interpreted as marine sediment. From biostratigraphy data indicated on Bathyal environment. Limestone interval maybe deposited from turbit current.

Determination of tectonostratigraphy boundaries for Beta well based on age and gamma ray log value equivalent. Beside that, with the isochron map analysis of early syn rift phase, can be known that nothing syn rift interval that was deposited (fig. 11.). Just only post rift sediment that was deposited. From post interval, range from 2.600' till 3.750' was composed of shale, sandstone, coal, and association with acid volcanic bed. This interval interpreted as beach deposition that changed to marine sediments. From well cuttings were indicated on land to transition environment. Upon this interval were deposited limestone and dolomit that marked by transgression process to marine environment and litoral condition.

\subsection{The Tectonostratigraphy of Research Area}

to analyze the development of basin, be used tectonostratigraphy approachment. beside using reflector pattern method, this analysis used mapping approachment based on thickness of tectonostratigraphy interval. From previous explanation that in research area divided into three interval: early syn rift, late syn rift, and post syn rift (fig. 8.)

1. Early syn rift interval.

Based on seismic line SM 05-17 (fig. 9.), can be seen that reflector pattern of early syn rift phase shows that there is thickening pattern to fault boundary. This indicated that faults controlled deposition of early syn rift phase in research area. On seismic section and isochron map of early syn rift (fig. 12.), also can be seen that fault patterns, NE-SW trend, controlled thickening pattern on early syn rift interval. Based on fault patterns and sediment thickening can be interpreted that the forming of rifting was controlled by tension tectonic force (NW-SE trend). In the map, can be seen thickening sediment in SW part, but no faults founded that controlled sediment thickening. About this, maybe there are other faults that controlled sedimentation but its position are outside of research area.

Based on analysis on Alfa Well, the deposition environment of early syn rift is beach. But on Beta Well, was interpreted as land because nothing sediment of early rift phase that was deposited. This interpretation result then be used for depositional environment analysis in other area in SM 05-17 (fig. 13.). From depositional environment interpretation, there are two depositional environments: beach and shallow marine. For every depositional environment having seismic facies reflection characteristics. The characteristics as follow:

1. Beach: continuous, low frequency, mediumstrong amplitude, and internal reflection is parallel.

2. Shallow marine: continuous, low frequency, low-medium amplitude, and internal reflection is divergent-chaotic.

Especially on shallow marine depositional environment on the right tip SM05-17 section, can be seen seismic reflection which have strong amplitude and located near fault plane. This reflection interpreted as talus sediment.

2. Late syn rift interval.

Based on seismic line SM 05-17 (fig. 9), can be seen that reflector pattern of late syn rift phase shows that there is thickening pattern to boundary fault. This indicated that faults controlled deposition of late syn rift phase in research area.

On the isochron map of late syn rift (fig. 14), can be seen its pattern is as same as early syn rift pattern. But in this phase the distribution of sediment is larger than early syn rift phase. Tectonic force interpretation on this phase is as same as early syn rift phase that is NW-SE trend (fig. 15)

Based on analysis on Alfa Well, the depositional environments of late syn rift phase are beach till shallow marine. But on Beta Well, was interpreted as land because nothing sediment of late syn rift phase that was deposited. This interpretation result then be used for depositional environment analysis in other area in SM 05-17 (fig. 15). from depositional environment interpretation, there are two depositional environments: beach that changed to shallow marine and shallow marine changed to deep marine. For every depositional environment having seismic facies reflection characteristics. The characteristics as follow:

1. Beach till shallow marine: continuous, low frequency, medium- strong amplitude, and internal reflection is divergent.

2. Shallow marine till deep marine: continuous, high frequency, low-medium amplitude, and internal reflection is divergent.

The strong amplitude and near fault plane are interpreted as talus sediment. It is same interpretation on early syn rift phase. 


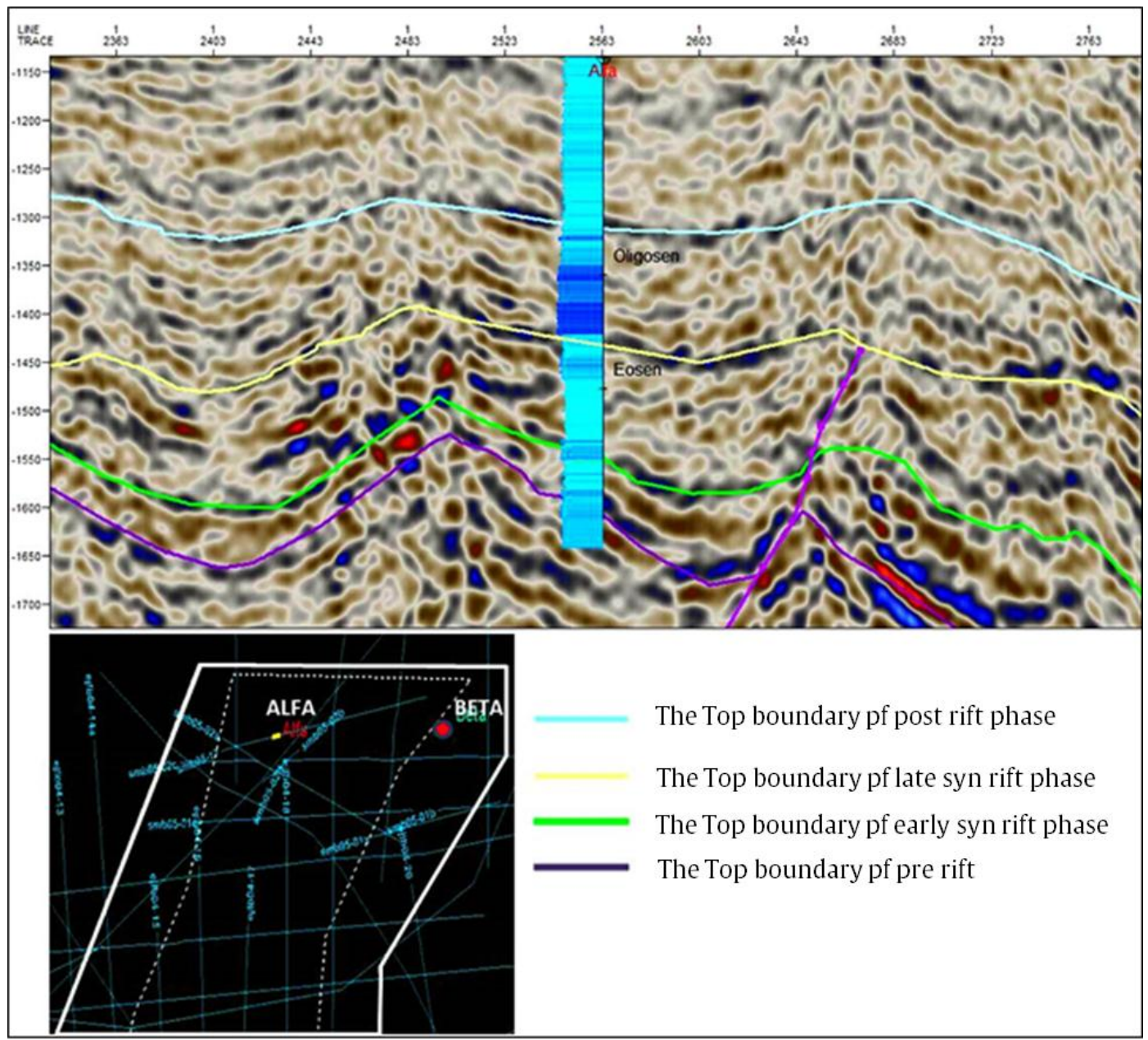

Fig. 8. The relations tectonostratigraphy boundaries on SM05-17 section that passed Alfa control well

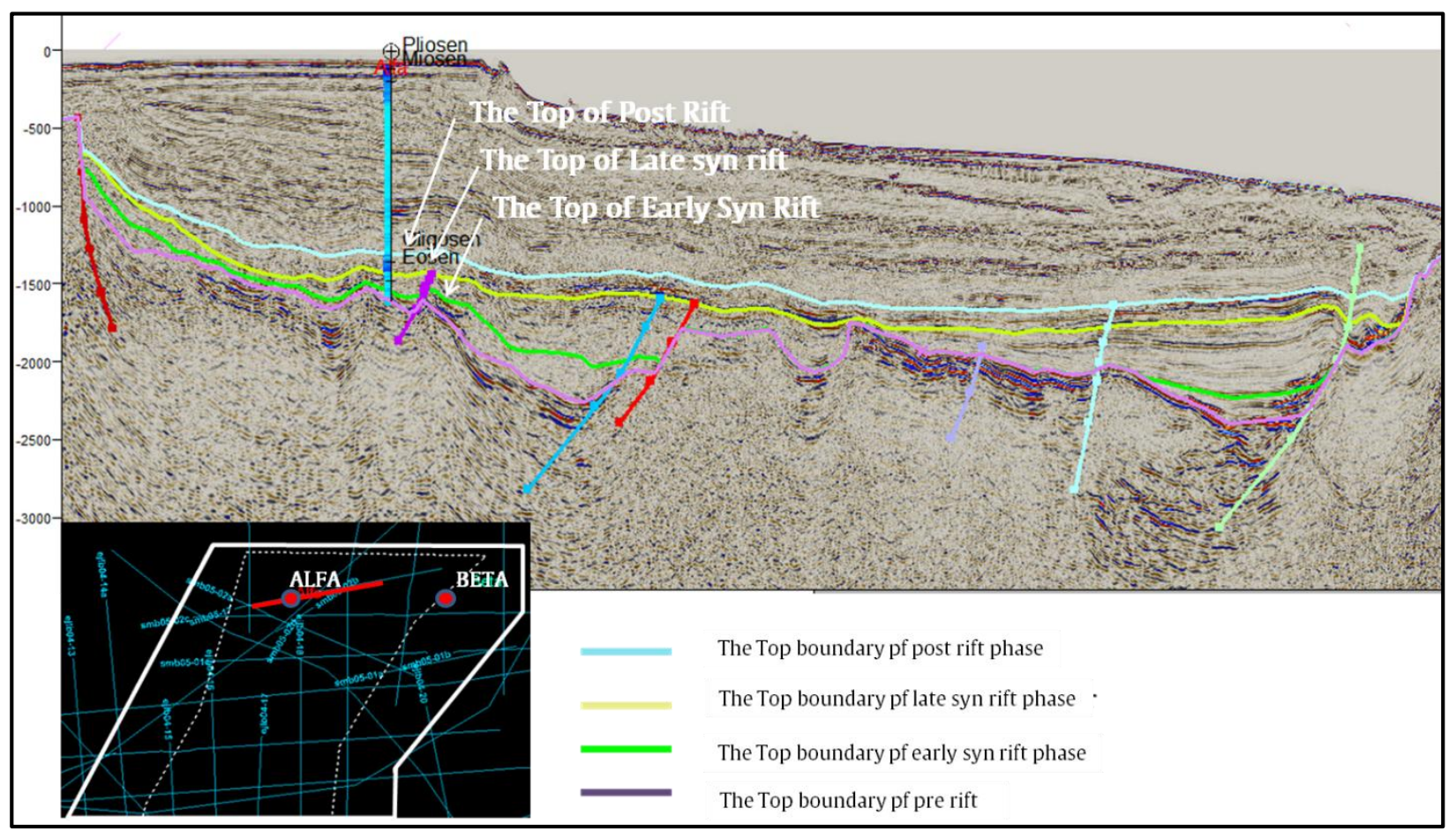

Fig. 9. Alfa well position on SM05-17 section which located on flexural margin area 


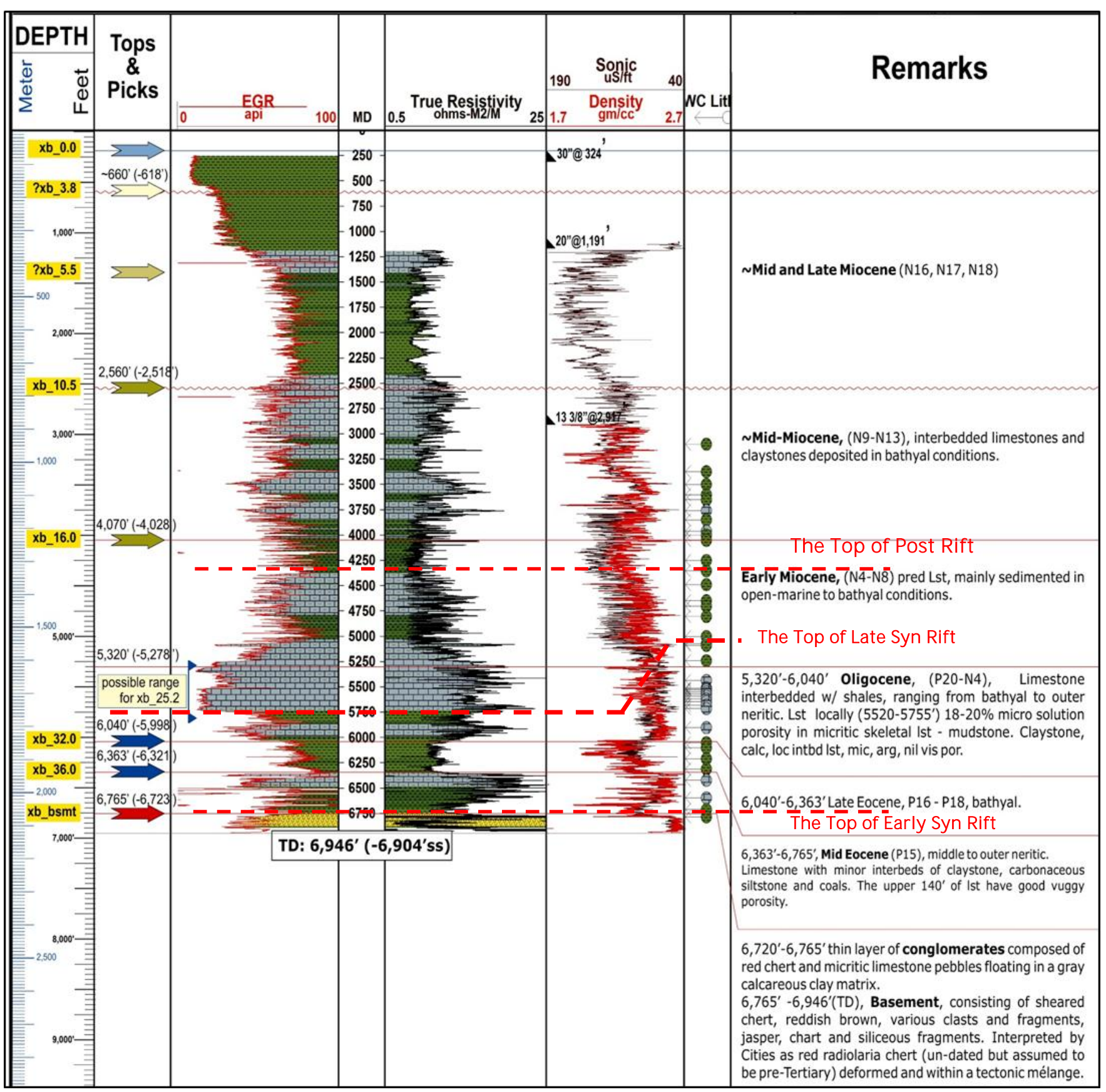

Fig. 10. Lithology characteristics that composed tectonostratigraphy intervals on Alfa Well (flexural margin area)

3. Post rift interval.

Based on SM 05-17 section (fig. 16), can be seen that the reflector pattern of post rift phase shows that there is thinning pattern to the margin of basin and thickness is not controlled by faults. This indicated that faults did not controlled the sedimentation of post rift phase in research area.

Based on analysis on Alfa Well, the depositional environment of post rift phase is deep marine. But on Beta Well, is interpreted as beach till shallow marine. This interpretation result then be used for depositional environment interpretation in other area on SM05-!7 section. From depositional environment interpretation, there are two depostional environments, they are deep marine and beach that changed to shallow marine. For every depositional environment has seismic facies reflection characteristics. The characteristics as follow:

1. Deep sea: continuous, low frequency, mediumhigh amplitude, and internal reflection are wavy-sub parallel.

2. Beach till shallow marine: discontinuous, low frequency, low amplitude, and internal reflection is wavy. 


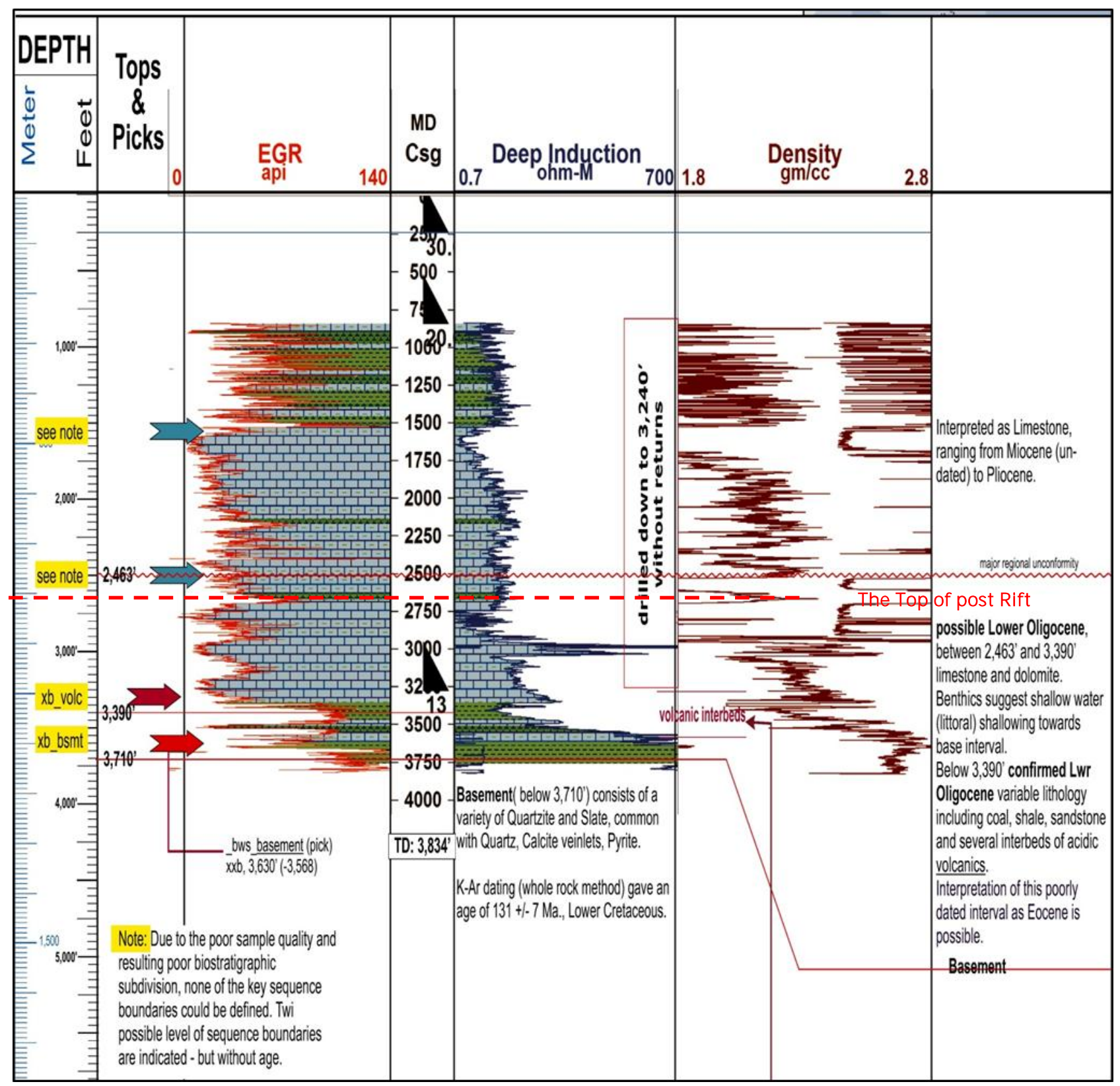

Fig. 11. Lithology characteristics that composed tectonostratigraphy intervals on Beta Well (flexural margin area) 

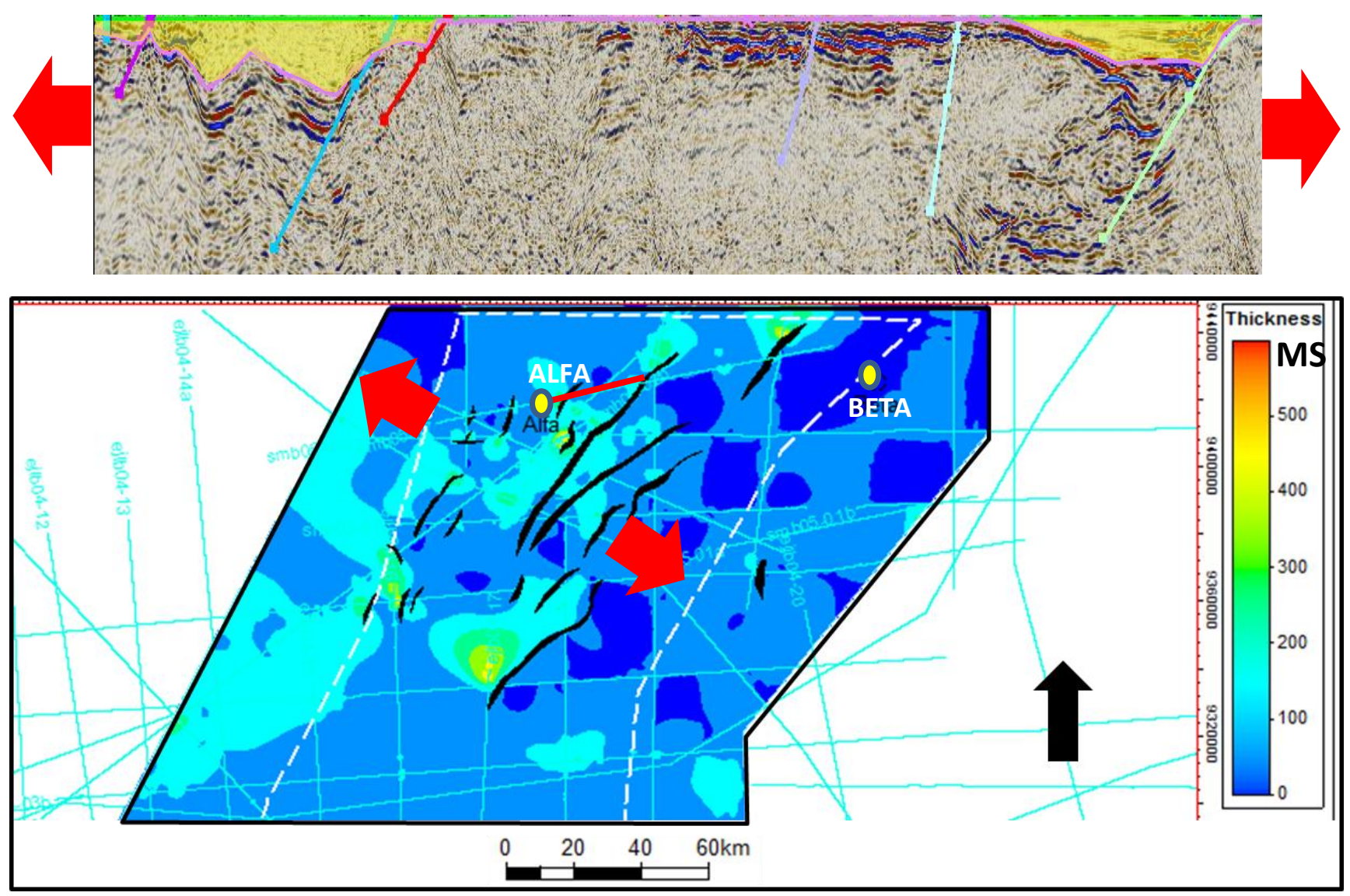

Fig. 12. Example from SM 05-17 section that has been flattened (upper) on the top of early syn rift and isochron map from early syn rift interval with tension force direction interpretation (arrow mark). The red line is section position 
Alfa Well

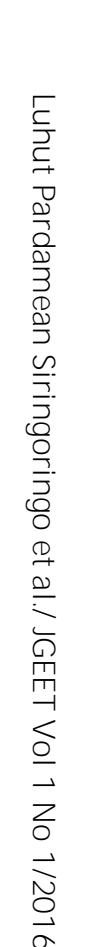

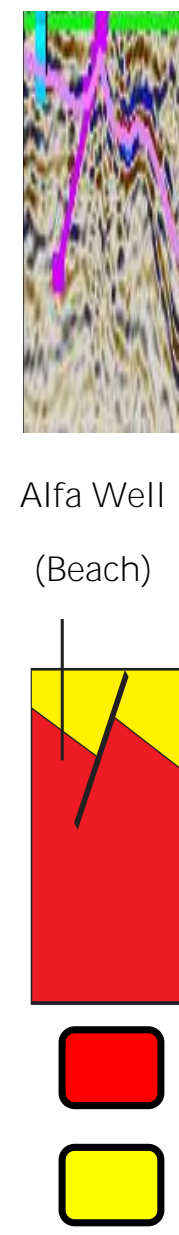

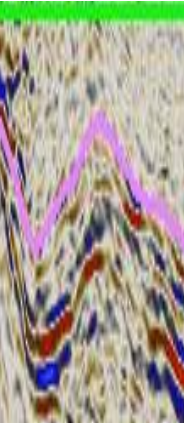
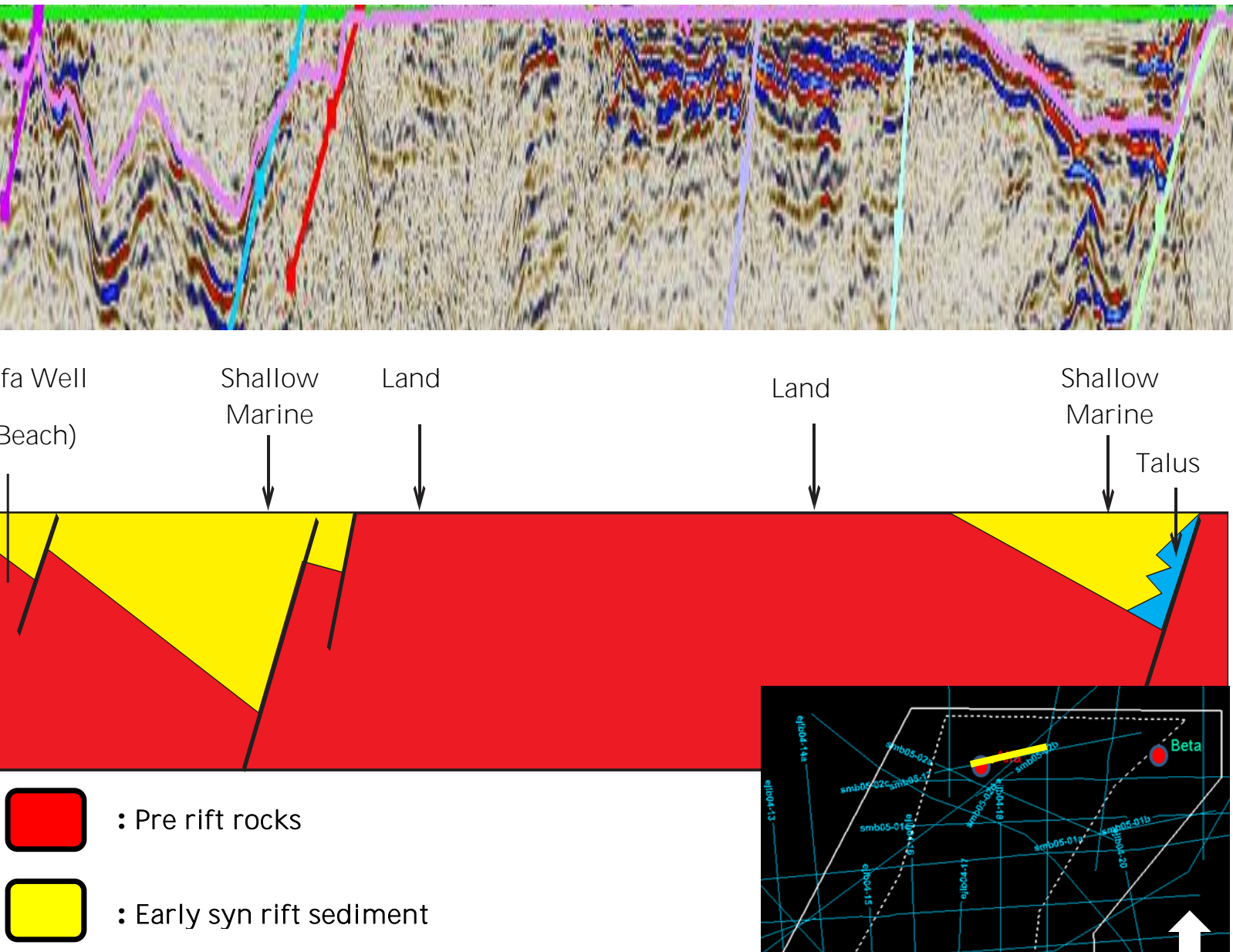

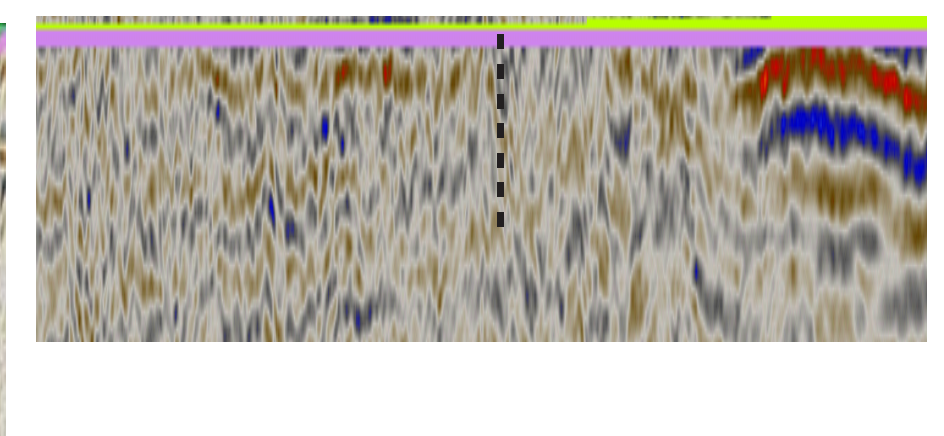

Beta Well

Land
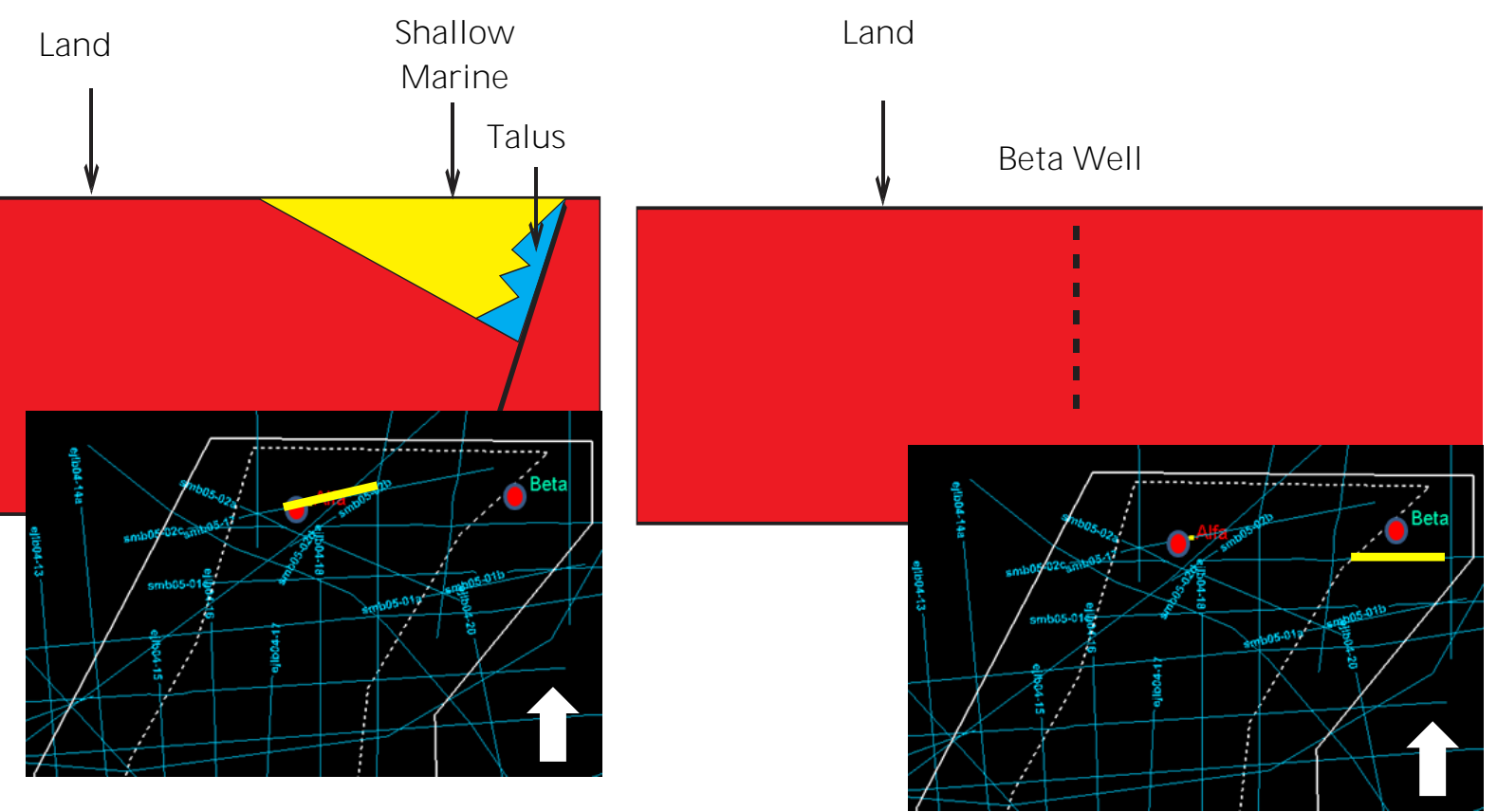

Fig. 13. The depositional environments interpretation of early syn rift on SM05-17 section (left) and depositional environment interpretation on SM05-02D (right) based on Beta well projection 

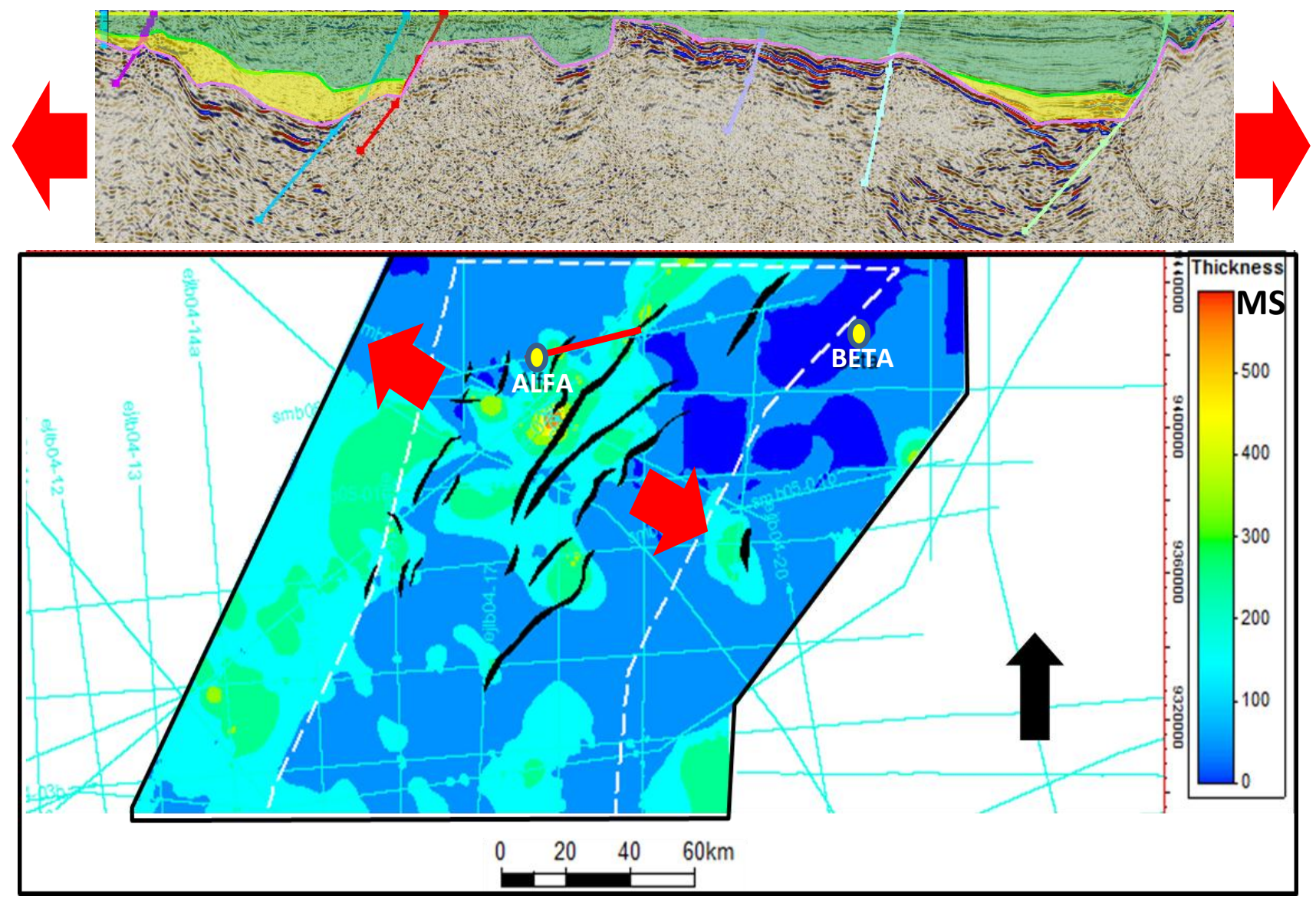

Fig. 14. Example from SM05-17 section that has been flattened (upper) on the top of late syn rift and isochron map from late syn rift interval with tension force direction interpretation (arrow mark). The red line is section position 


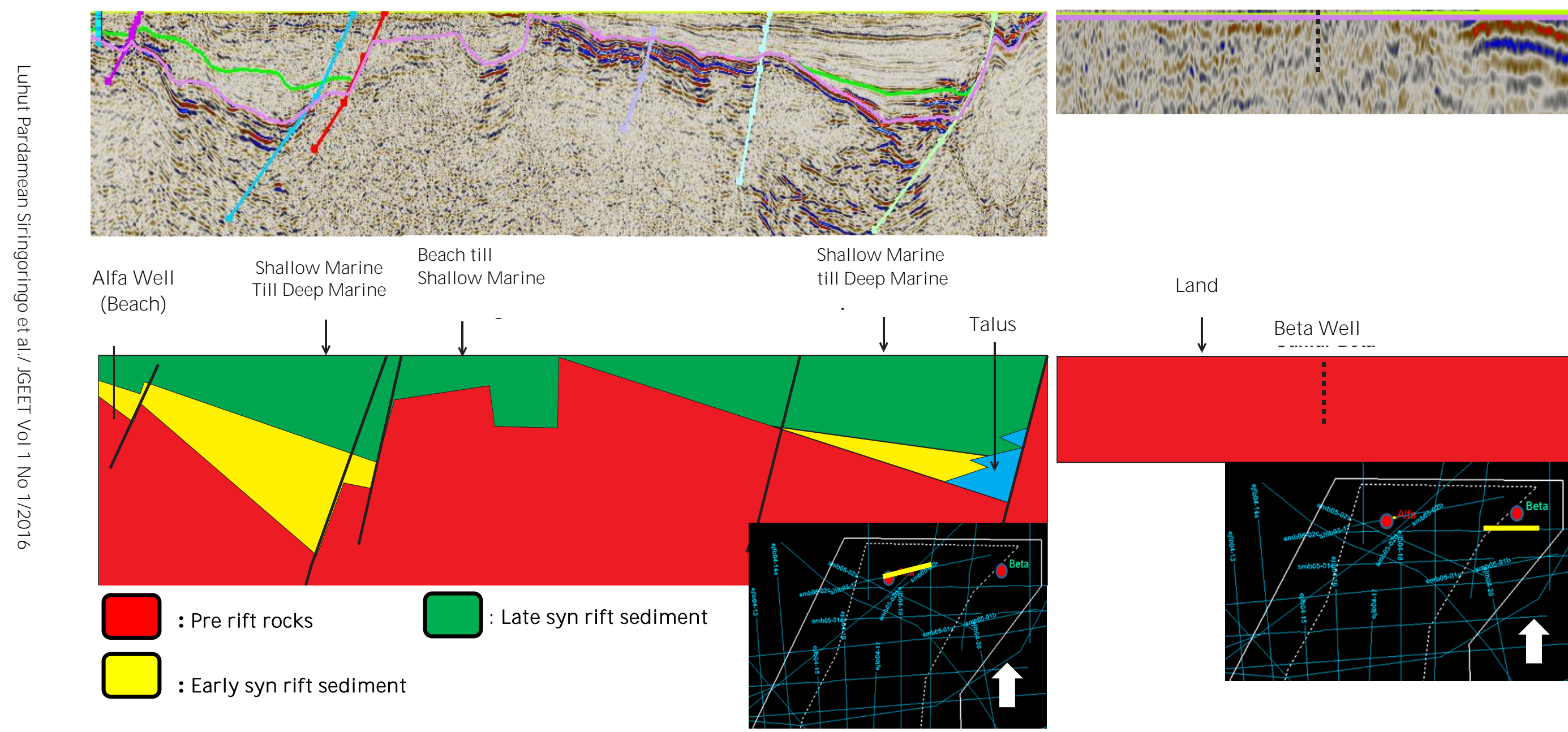

Fig. 15. The depositional environments interpretation of late syn rift on SM 05-17 section (left) and depositional environment interpretation on SM 05-02D (right) based on Beta well projection 

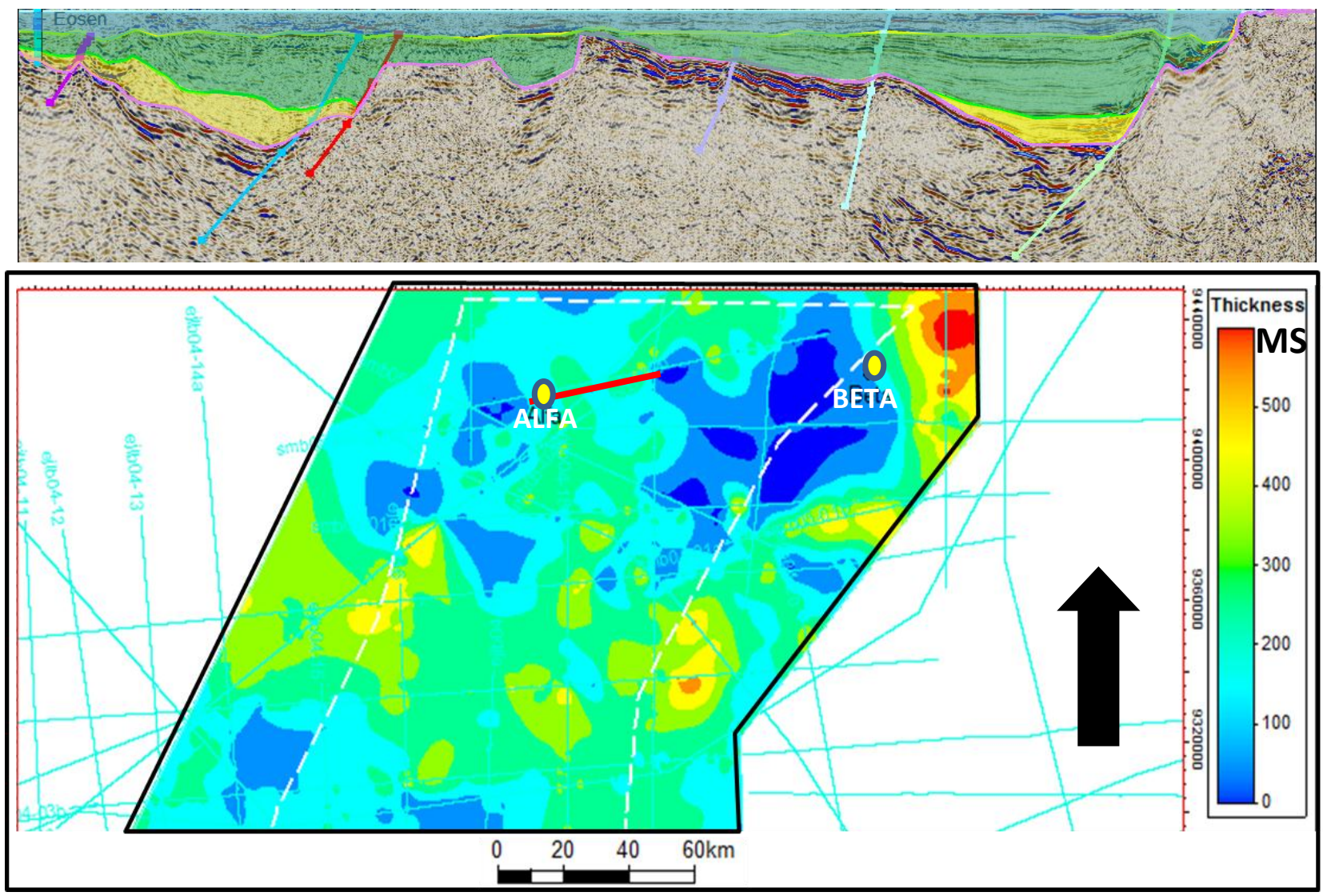

Fig. 16. Example from SM05-17 section that has been flattened (upper) on the top of post rift and isochron map from post rift interval. The red line is section position 
Alfa Well

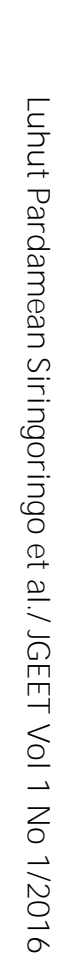
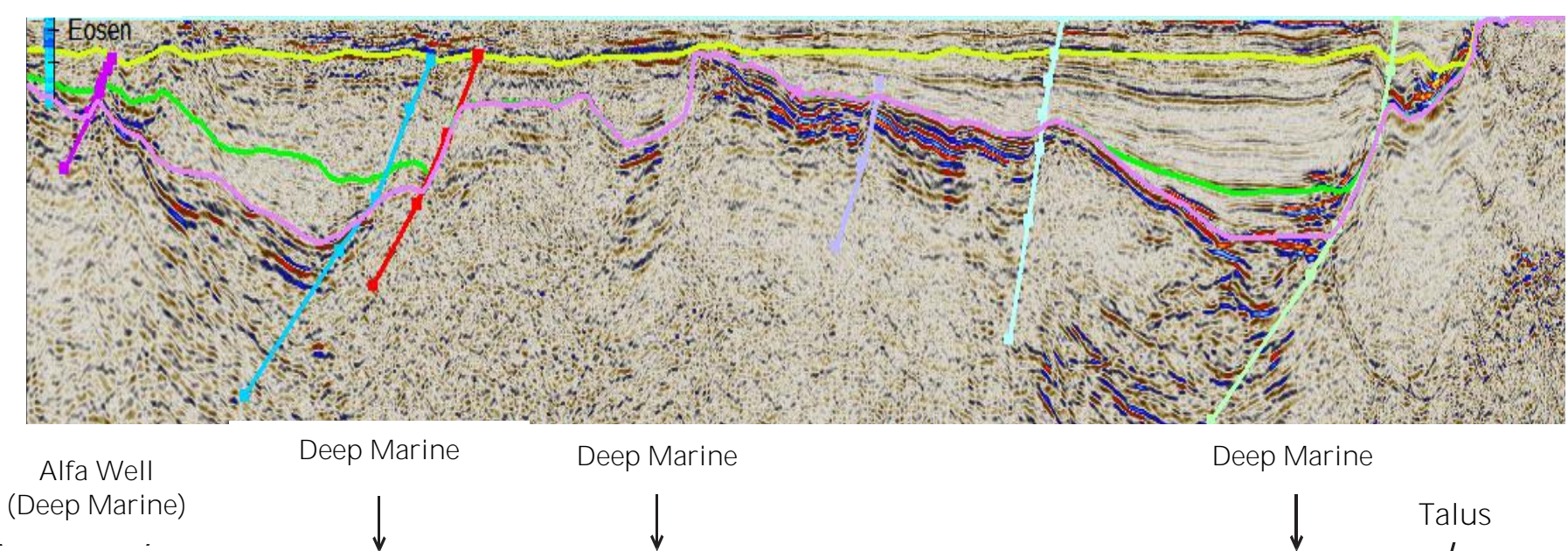

\section{(Deep Marine)}

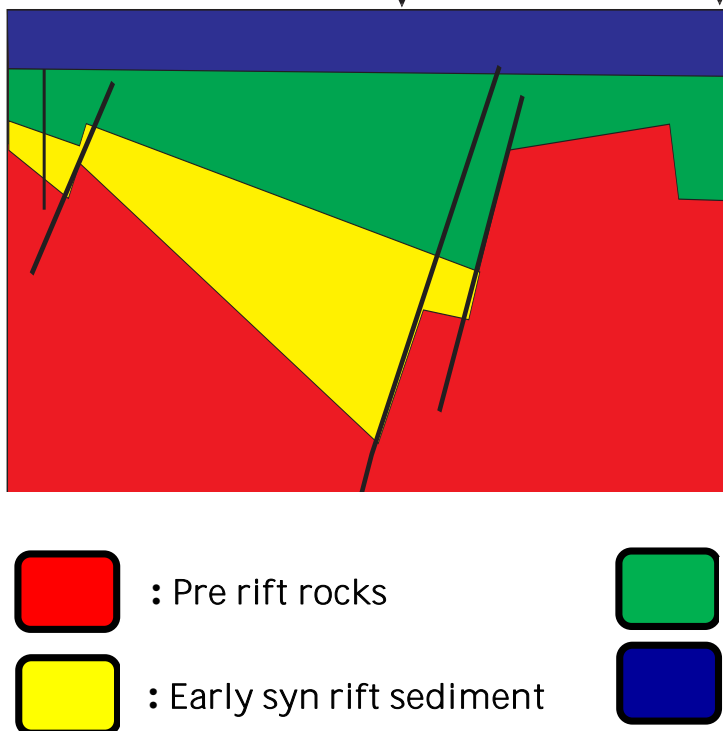

: Late syn rift sediment

Post Rift sediment
Beta Well

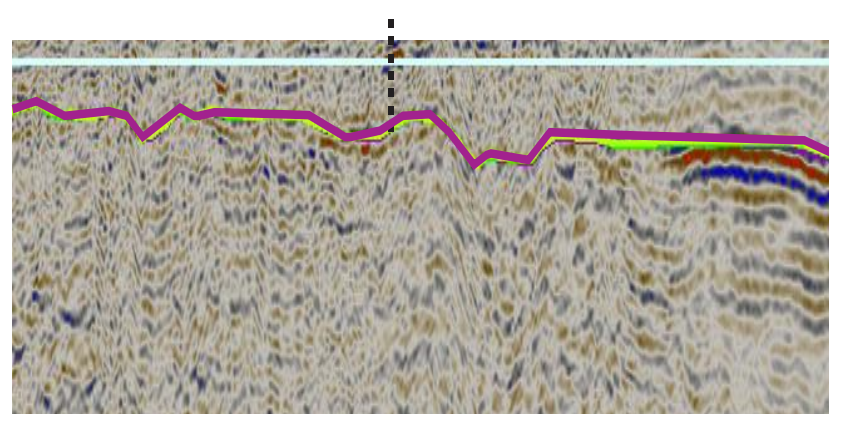

Beach till Shallow Marine

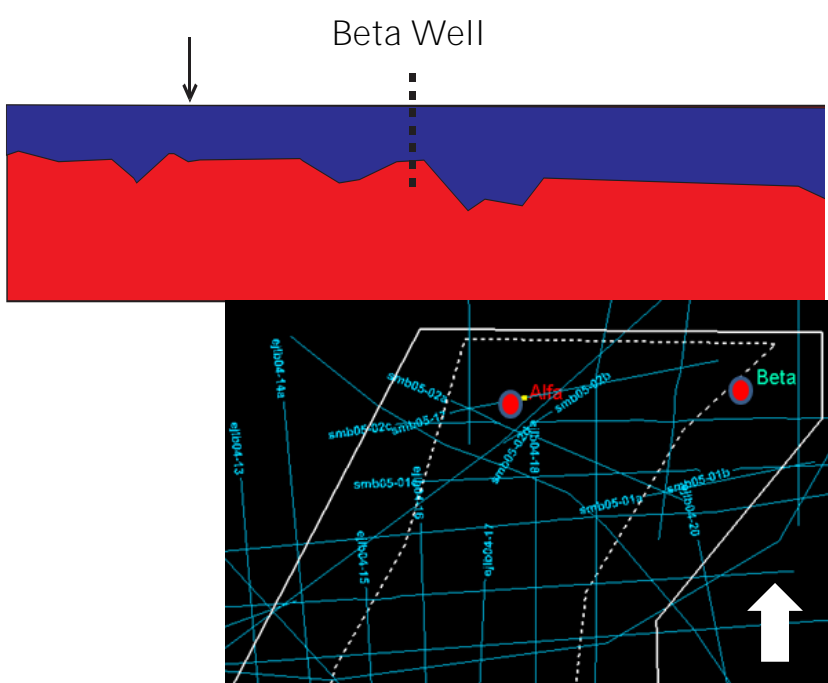

Fig. 17. The depositional environments interpretation of post rift on SM 05-17 section (left) and depositional environment interpretation on SM05-02D (right) based on Beta well projection 


\section{Conclusion}

The Paleogene Tectonostratigraphy intervals of research area can be divided into three phases: Pre Rift Phase, Early Syn Rift Phase (Middle Eocene), Late Syn Rift Phase (Middle Eocene), and Post rift Phase (Early Oligocene-Early Miocene). The development of Masalima Trench Basin was begun with rift basin formation on Middle Eocene which be controlled by tension tectonic with direction NW-SE and made half graben structures with direction NE-SW. Commonly, Masalima Trench can be categorized as aborted rift because of marked by post rift interval. The deposition of early syn rift sediment happen on litoral till neritic, late syn rift phase was deposited on Litoral till Batial condition Post rift phase sediment deposition happen on Batial. Deep marine sediments on post rift phase were distributed widely. it have distribution pattern direction NE-SW about parallel with current direction masalima trench.

\section{References}

[1] D. Ariyono, J. Kupecz, I. Sayers, C. A. Tanos, A.S Hilman. 2013. Generation and expulsion from middle eocene in The South Makassar Basin, Indonesia, Proceedings of the Indonesian Petroleum Association 37th Annual Convention, Indonesian Petroleum Association, p 4

[2] E. De Man, F. Ashby, J. Bacheller, A. Cahyono, Suriamin, J. Corthay, P. Hillock, S. Wilmot. 2011. Deep-water site investigation - Makassar Straits, Indonesia, Proceedings of the Indonesian Petroleum Association 35th Annual Convention, Indonesian Petroleum Association, $\mathrm{p} 4$.

[3] J.W. Granath, P.A. Emmet, M.G. Dinkelman. 2009. Crustal architecture of The East Java Sea-Makassar Strait region from long-offset crustal scale 2D seismic reflection imaging, Indonesia, Proceedings of the
Indonesian Petroleum Association 33th Annual Convention, Indonesian Petroleum Association, p12.

[4] R. Hidayat, S. Husein, S. Surjono. 2012: Regional Depositional Model of South Makassar Basin Depocenter Based on Seismic Facies, Indonesia, Journal SE Asian Application Geology, v 4, p 42-44.

[5] J. Kupecz, Ian Sayers, P. Tognini, A. Hilman, C. Tanos, D. Ariyono. 2013. New insight into The tectonostratigraphic evolution of The South Makassar Basin, Indonesia, Proceedings of the Indonesian Petroleum Association 37th Annual Convention, Indonesian Petroleum Association, $\mathrm{p} 4$.

[6] G.E. Pireno, C. Cook, D. Yuliong, S. Lestari. 2009. Berai carbonate debris flow as reservoir in The Ruby Field, Sebuku Block, Makassar Straits: a new exploration play in Indonesia, Proceedings of the Indonesian Petroleum Association 33th Annual Convention, Indonesian Petroleum Association, p 1-4.

[7] G.E. Pireno, Dardji. N. Darussalam. 2010. Petroleum system overview of The Sebuku Block and The Surrounding area: Potential as a new oil and gas province in South Makassar Basin, Proceedings of the Indonesian Petroleum Association 34th Annual Convention, Indonesian Petroleum Association, p 9.

[8] A.H. Satyana. 2008. Basin Analysis and Petroleum System, short course AAPG Student Chapter, AAPG, 44.

[9] A.H. Satyana, S. Damayanti, C. Armandita. 2012. Tectonics, stratigraphy, and geochemistry of The Makassar Straits: recent updates from exploring offshore west sulawesi, oppurtunities and risks, Proceedings of the Indonesian Petroleum Association 36th Annual Convention, Indonesian Petroleum Association, p 1-11.

[10] C.A. Tanos, J. Kupecz, A.S. Hilman, D. Ariyono, Ian Sayers. 2013. Diagenesis of carbonate debris deposits from The Sebuku Block, Makassar Strait, Indonesia, Proceedings of the Indonesian Petroleum Association 37th Annual Convention, Indonesian Petroleum Association, $\mathrm{p} 1$. 